Aquatic Invertebrate Sampling

at Selected Outfalls in Operable Unit 1082;

Technical Areas 9, 11, 16, and 22

Saul Cross

DISTRIBUTION OF THIS DOCUMENT IS UNLMITED 



\section{DISCLAIMER}

Portions of this document may be illegible in electronic image products. Images are produced from the best available original document. 



\section{TABLE OF CONTENTS}

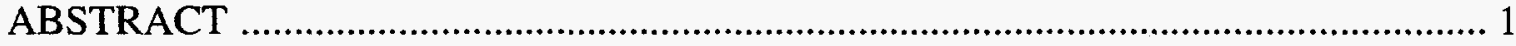

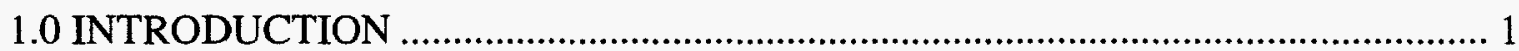

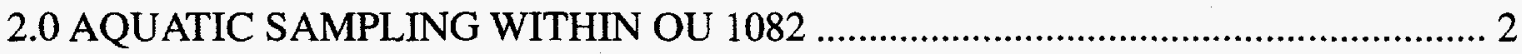

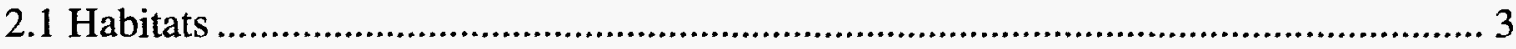

2.2 Aquatic invertebrate sampling .......................................................................... 3

2.3 Aquatic invertebrate analysis ................................................................................ 4

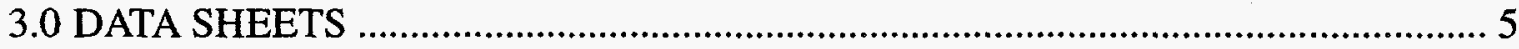

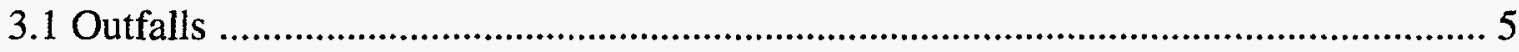

3.1.1 Outfall 128128, Building 22-91, 16 November 1994 _...................................... 6

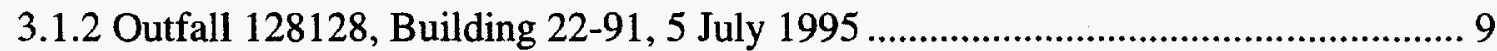

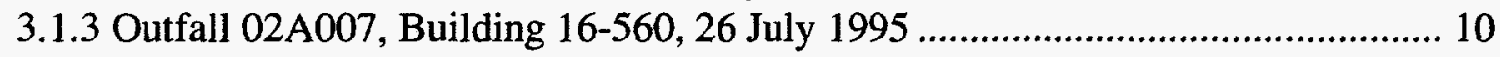

3.1.4 Outfall 03A060, Building 16-430, 13 October 1994 ……..................................... 16

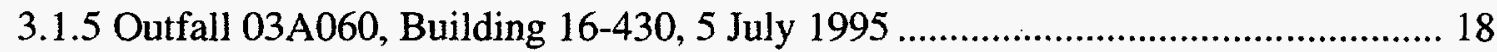

3.1.6 Outfalls 04A157 and 05A072, Building 16-460, 29 June 1995 ........................... 19

3.1.7 Outfall 05A053, Building 16-410, 13 October 1994 …...................................... 22

3.1.8 Outfall 05A053, Building 16-410, 29 June 1995 .................................................. 24

3.1.9 Outfall 05A054 (Fish Ladder), Building 16-340, 1 July 1994 ............................ 26

3.1.10 Outfall 05A054 (Fish Ladder), Building 16-340, 22 June 1995 ........................ 28

3.1.11 Outfall 05A056, Building 16-260, 29 June 1995 .............................................. 30

3.1.12 Outfall 05A058, Buildings in the 16-300 line, 22 June 1995 ............................ 31

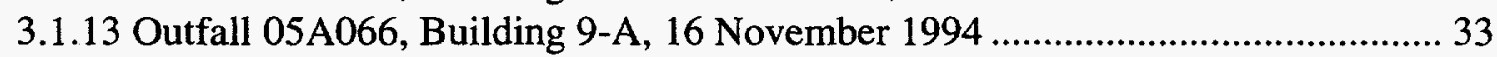

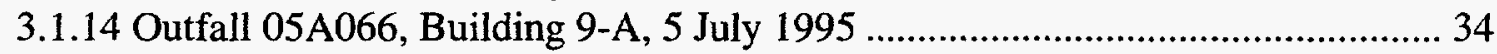

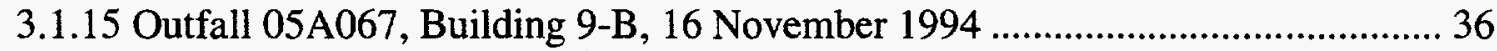

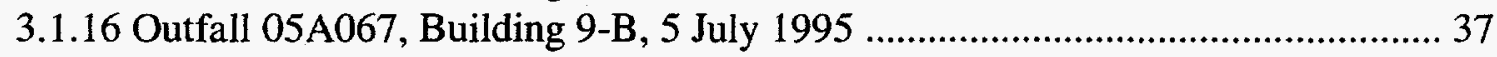

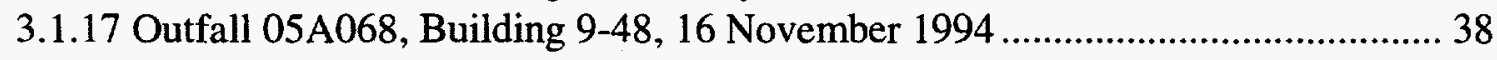

3.1.18 Outfalls 05A069 (K site), Building 11-50, 13 October 1994 ............................ 39

3.1.19 Outfalls 05A072 and 04A157, Building 16-460, 29 June 1995 ......................... 40

3.2 Natural waterways within the area ......................................................................... 43

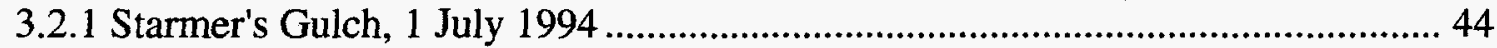

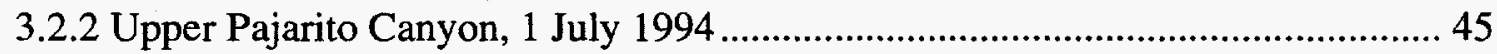

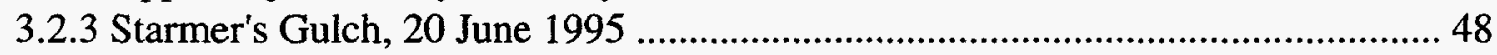

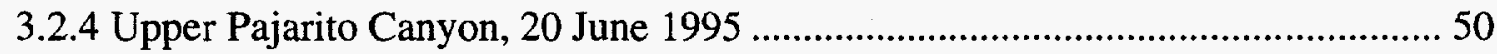

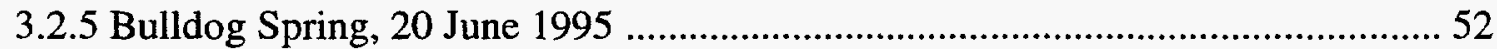

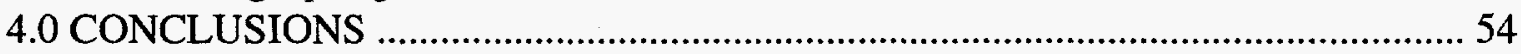

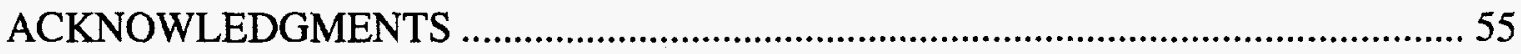

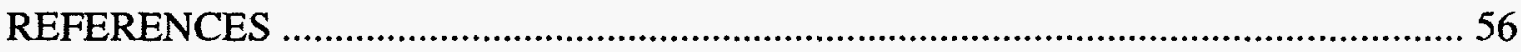




\title{
AQUATIC INVERTEBRATE SAMPLING AT SELECTED OUTFALLS \\ IN OPERABLE UNIT 1082; TECHNICAL AREAS 9, 11, 16, AND 22 \\ by \\ Saul Cross
}

\begin{abstract}
The Ecological Studies Team (EST) of ESH-20 at Los Alamos National Laboratory conducted preliminary aquatic sampling at outfalls within Operable Unit 1082 and nearby "natural waterways." Eleven outfalls were sampled a total of eighteen times. Three natural waterways (upper Pajarito Canyon, Starmer's Gulch, and Bulldog Spring) in the vicinity were sampled a total of six times. At most sites, EST recorded hydrological condition, physico-chemical parameters, wildlife uses, and vegetation. At each outfall with water and each natural waterway, EST collected an aquatic invertebrate sample which was analyzed by taxa composition, Wilhm's biodiversity index, the community tolerance quotient (CTQ), and density.

The physico-chemical parameters at most outfalls and natural waterways fell within the normal range of natural waters in the area. However, the outfalls are characterized by low biodiversity and severely stressed communities composed of a restricted number of taxa. The habitat at the other outfalls could probably support well-developed aquatic communities if sufficient water was available. At present, the hydrology at these outfalls is too slight and/or sporadic to support such a community in the foreseeable future. In contrast to the outfalls, the natural waterways of the area had greater densities of aquatic invertebrates, higher biodiversities, and lower CTQs.
\end{abstract}

\subsection{INTRODUCTION}

In 1972, the U. S. Environmental Protection Agency (EPA) formed the National Pollutant Discharge and Elimination System (NPDES) program. Under terms of the NPDES program, dischargers are required to monitor their effluents to demonstrate compliance with effluent limitations. Los Alamos National Laboratory (LANL) currently discharges treated wastewater from more than 100 outfalls (Bailey 1995), all of which operate under NPDES permits. These permits establish maximum levels for pollutant discharge. Many LANL outfalls discharge into drainages that would be dry otherwise.

LANL has compiled extensive water quality data for outfall effluents, but little documentation of resident aquatic invertebrate communities within LANL outfalls has occurred. It is now widely accepted that chemical criteria and toxicity testing are insufficient to detect the cumulative stressor effects on an aquatic community (Jackson et al. 1994). Biomonitoring, the use of aquatic organisms to measure and document water quality, is currently used in aquatic systems assessments to supplement more traditional methods 
(Karr 1991; EPA 1991). Sections 303 and 304 of the Clean Water Act currently require states to integrate biological criteria into their water quality standards (EPA 1990).

Aquatic invertebrates have been used extensively as water quality indicators. These organisms, especially the stream-dwelling insects, are well suited as in situ biomonitors due to their

- abundance in virtually all freshwater streams

- small size and total immersion in the water environment

- relatively sedentary life styles, making them good indicators of local conditions

- differential sensitivities to various types of impairment, including non-point source pollution

- life cycles frequently of at least one-year duration, permitting detection of past disturbance

- relative ease of collection and identification to family or genus level

Monitoring only the physical and chemical characteristics of water provides little information of conditions prior to the sampling date. In contrast, shifts in aquatic invertebrate numbers and taxa present can indicate disturbances that occurred long before the sample is taken. These disturbances could result from infrequent discharges of waste that might remain undetected through a water quality monitoring program that did not incorporate biological data (Weber 1973).

\subsection{AQUATIC SAMPLING WITHIN OU 1082}

Operable Unit (OU) 1082 lies within the southwestern quadrant of LANL, Los Alamos, New Mexico. The OU is bounded on the north by Cañon de Valle, on the east by OUs 1086 (TA-15) and 1144 (TA-49), on the south by State Highway 4 and Bandelier National Monument, and on the west by West Jemez Road and Santa Fe National Forest. Elevation ranges from approximately $2347 \mathrm{~m}(7,700 \mathrm{ft})$ at the west end to approximately $2040 \mathrm{~m}(6,800 \mathrm{ft})$ at the lower east end.

Several outfalls of differing types are located with OU 1082 (Fig. 1). Due to recent project consolidations and water minimization practices, effluent discharges to many of these outfalls have been significantly reduced or entirely eliminated. Various projects within the OU have proposed further reductions and eliminations to these and other outfalls. To document resident aquatic invertebrate communities within the area, the Ecological Studies Team (EST) of ESH-20 conducted preliminary surveys of outfalls within OU 1082. 


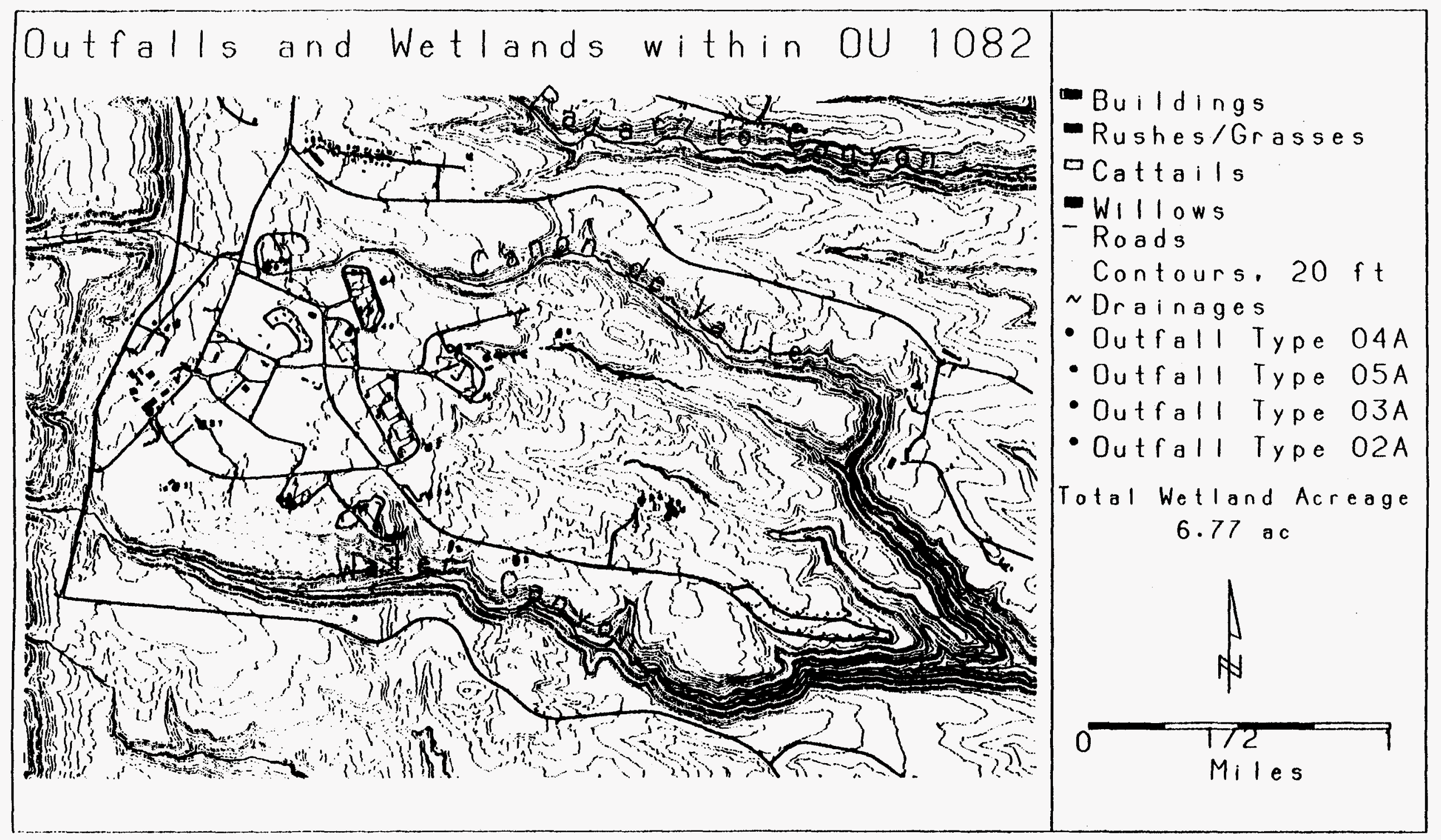




\subsection{Habitats}

In this report, the term "wetlands" refers to areas supporting hydrophytic vegetation or containing surface water. The term does not refer to jurisdictional wetlands, which are defined by the presence of hydrophytic vegetation, hydrology, and hydric soils. Our surveys did not test for hydric soils.

One purpose of our surveys was to determine the quality of aquatic habitat below outfalls. In addition to collecting aquatic invertebrate samples, EST measured field parameters and noted various field characteristics deemed useful in assessing habitat condition:

- Hydrology, i.e. a rough estimate of the amount of water flowing from the outfall and the length of surface water beyond the point of discharge.

- At outfalls with flowing water, field team members measured dissolved oxygen, conductivity, $\mathrm{pH}$, and water temperature.

- Wildlife uses in the immediate vicinity of the outfalls were recorded.

- Dominant trees and shrubs of the surrounding area were noted. All plant species found within a drainage and/or riparian community were numerically ranked by abundance according to the following scale:

$$
\begin{aligned}
& 1=\text { very abundant } \\
& 2=\text { abundant } \\
& 3=\text { common } \\
& 4=\text { occasional } \\
& 5=\text { infrequent }
\end{aligned}
$$

\subsection{Aquatic invertebrate sampling}

Aquatic invertebrate sampling techniques are classified (EPA 1990) as

- qualitative - used to make site comparisons to determine the presence or absence of invertebrates having varying degrees of tolerance to pollutants and to obtain information on taxa richness,

- semi-quantitative - used when samples are standardized by level of effort (e.g., time expended per habitat) or an approximate sampling area is defined, or

- quantitative - used to provide an estimation of the numbers or biomass of the various community components per unit area, volume, or sampling unit.

Outfalls sampled within OU 1082 contained insufficient water to permit invertebrate collection with a Surber sampler (quantitative), a Hess sampler (quantitative), or a kicknet (semi-quantitative). We therefore sampled all observed aquatic habitats at each outfall with a D-frame dipnet. Although this type of sampling does not permit an estimation of biomass, it was deemed adequate for this preliminary study.

Greater volumes of water present in the natural waterways permitted the use of quantitative and semi-quantitative sampling devices. EST used a kicknet and sub-sampling (Cross 1994) to sample the Starmer's Gulch area in July 1994. All other natural waterway sites were sampled with a Surber sampler in riffle areas. A Surber sampler defines one square foot of sampling area and permits fairly accurate calculations of invertebrate 
densities. Calculated values were converted to numbers of individuals per square meter, the standard unit of aquatic invertebrate densities.

\subsection{Aquatic invertebrate analysis}

Standard reference keys (Merritt and Cummins 1984; Wiggins 1977; Baumann, et al. 1977; Edmunds, et al. 1976; McCafferty 1981; Pennak 1978) were used to identify aquatic invertebrates. Identifications were taken to the lowest level deemed reasonable when considering both required time and the study's preliminary nature. Dr. Gerald Z. Jacobi of New Mexico Highlands University reviewed all questionable identifications. EST archived all collected aquatic invertebrates in its permanent collection at ESH-20.

For each aquatic invertebrate collection, a biodiversity index was calculated using the equation discussed by Wilhm (1967):

$$
\mathrm{D}=(\mathrm{S}-1) / \ln \mathrm{N}
$$

where

$$
\begin{aligned}
& D=\text { the taxa diversity index } \\
& S=\text { the number of taxa } \\
& N=\text { the number of individuals }
\end{aligned}
$$

The derived number is a good indicator of the site's taxa richness and evenness. A diversity index value of less than one indicates heavy pollution, between one and three indicates moderate pollution, and greater than three indicates clean water. However, biodiversity values for low-order montane streams are notoriously low and should not be compared to higher order and lower elevation streams.

A special effort was made to ensure that taxa were not counted twice; and if a counting error occurred, it was due to under-counting rather than over-counting. Therefore, we only counted one taxon in a sample for the following cases:

- different life stages of a taxon present

- specimen(s) keyed to the family level and another specimen(s) in the same family identified to a lower level

- possible different instars of a genus assigned separate descriptive, rather than taxonomic, identifications

Tolerance quotients measure an aquatic invertebrate's endurance to stressful conditions based upon tolerances to alkalinity, sulfates, and sedimentation (Winget and Magnum 1989). Invertebrates adapted to life in an impaired zone have high tolerance quotients, with 108 being the highest possible. The community tolerance quotient (CTQ) is calculated by averaging the quotients of all invertebrates collected at a site. The quotient measures an aquatic community's overall condition over the preceding several months. A high CTQ (above 90) indicates an aquatic community that has undergone severe, and often repeated, disturbance. 


\subsection{DATA SHEETS}

\subsection{Outfalls}

EST consulted ESH-18 (Water Quality and Hydrology) personnel to determine which outfalls should be sampled, and we took samples at most OU 1082 outfalls with flowing water. This report documents conditions at 12 outfalls, with the majority of aquatic sampling occurring in autumn 1994 and summer 1995. In autumn 1994, sampling was curtailed by the advent of freezing temperatures that could significantly impact aquatic invertebrate communities.

Each outfall is designated with a six-digit number: the first three digits being its EPA category and the last three numbers being its NPDES serial number. This number is followed by the number of the building associated with the outfall. Fifteen of the eighteen outfalls sampled were high-explosive wastewater outfalls (EPA category 05A). One boiler blowdown (EPA category 02A), treated cooling water (EPA category 03A), and one noncontact cooling water outfall (EPA category 04A) were also sampled.

The collected data from each outfall was entered into a standardized data sheet consisting of the following categories:

- Hydrology

- Wildlife use

- Vegetation

- Physico-chemical parameters

- Aquatic invertebrates

Aquatic invertebrate data is presented in terms of taxa composition, biodiversity, and the CTQ. Conditions at the outfalls are discussed at greater length in the conclusions section. 


\subsubsection{Outfall 128128, Building 22-91, 16 November 1994}

Hydrology: The discharge pipe produced only a trickle of water. Small standing pools occurred within the cattail area.

Wildlife use: High, with isolated pools heavily used as wallows for elk and possibly other mammals.

Vegetation: The surrounding overstory consists of ponderosa pine (Pinus ponderosa), with a few small one-seeded junipers (Juniperus monosperma). Immediately below the discharge pipe is an area of scattered cattails and sedges. Approximately 40 yards below the discharge pipe, the cattails become much more concentrated and a "true" wetlands area commences at an elevation of $2211 \mathrm{~m}$ (7300 ft). The cattail marsh covers approximately 0.8 acre. The vegetative abundance surveys were conducted for

\begin{tabular}{|l|l|c|}
\hline \multicolumn{1}{|c|}{ Scientific name } & \multicolumn{1}{|c|}{ Common name } & $\begin{array}{c}\text { Abundance } \\
\text { ranking }\end{array}$ \\
\hline Typha latifolia & Cattails & 1 \\
\hline Agrostis alba & Redtop & 3 \\
\hline Bromus anomalus & Nodding brome & 4 \\
\hline Andropogon scoparius & Little bluestem & 4 \\
\hline Elymus canadensis & Canadian wildrye & 4 \\
\hline Rosa woodsii & Wild rose & 4 \\
\hline Carex sp. & Sedge & 4 \\
\hline Scirpus acutus & Bulrush & 4 \\
\hline Muhlenbergia wrightii & Spike muhly & 5 \\
\hline Artemisia dracunculus & Wormwood & 5 \\
\hline Agropyron trachycaulum & Slender wheatgrass & 5 \\
\hline Poa fendleriana & Mutton grass & 5 \\
\hline Sporobolus contractus & Spike dropseed & 5 \\
\hline Antennaria parvifolia & Pussytoes & 5 \\
\hline
\end{tabular}


approximately 150 yards within the riparian zone.

Physico-chemical parameters: Measurements were taken at the discharge pipe although water flow was slight. The conductivity readings are unusually high. The dissolved oxygen readings are suspect since the average is $118 \%$ of the saturation value at $17.5 \infty \mathrm{C}$.

\begin{tabular}{|c|c|c|c|c|}
\hline Measurement & Trial 1 & Trial 2 & Trial 3 & Average \\
\hline $\begin{array}{c}\text { Dissolved } \\
\text { oxygen (mg/I) }\end{array}$ & 8.65 & 8.85 & 9.0 & 8.83 \\
\hline $\begin{array}{c}\text { Temperature } \\
\text { (degrees } \\
\text { Celsius) }\end{array}$ & 17.5 & 17.5 & 17.5 & 17.5 \\
\hline $\begin{array}{c}\text { Conductivity } \\
(\mu \mathrm{mhos} / \mathrm{cm})\end{array}$ & 756 & 765 & 763 & 761 \\
\hline $\mathbf{p H}$ & 8.5 & 8.4 & 8.3 & 8.4 \\
\hline
\end{tabular}

Aquatic Invertebrates: We sampled for aquatic invertebrates in standing water above and within the cattail thickets.

Taxa composition

\begin{tabular}{|c|c|c|c|c|}
\hline $\begin{array}{c}\text { Number of } \\
\text { individuals }\end{array}$ & Order & Family & Genus & $\begin{array}{c}\text { Tolerance } \\
\text { quotient }\end{array}$ \\
\hline $\begin{array}{c}\text { approximately } \\
300\end{array}$ & Ostracoda & Candodidae & & 108 \\
\hline 17 & Ephemeroptera & Baetidae & Baetis & 72 \\
\hline 5 & Diptera & Tabanidae & Chrysops & 108 \\
\hline 1 & Diptera & Chironomidae & Type A & 108 \\
\hline 1 & Diptera & Chironomidae & Type C & 108 \\
\hline 4 & Diptera & Culicidae & Culex & 108 \\
\hline 2 & Diptera & Culicidae & Culiseta & 108 \\
\hline 2 & Diptera & Culicidae & pupae & 108 \\
\hline
\end{tabular}




\section{Biodiversity}

Number of taxa $=7$

Number of individuals $=332$

Wilhm's biodiversity index $=1.03$

\section{Community Tolerance Quotient}

The CTQ for outfall 128128 was 106 . Omitting the ostracods causes it to fall to 89 , still a relatively high value. All except one of the Baetid mayflies were collected in one pool, and this single refugium greatly lowered the community value. The pool containing the mayflies was thoroughly sampled to ensure that no other "sensitive" biological indicators were overlooked, and none were found. 


\subsubsection{Outfall 128128, Building 22-91, 5 July 1995}

Hydrology: This outfall is no longer used, and there was no flow. Some damp places along the drainages and several stagnant pools, apparently due to storm water runoff.

Wildlife use: Bedding in rushes and grasses, elk scat and tracks showing moderate use. Vegetation: Done previously.

Physico-chemical parameters: None taken due to lack of flow.

Aquatic invertebrates: We sampled for aquatic invertebrates in several of the stagnant pools.

\section{Taxa composition}

\begin{tabular}{|c|c|c|c|c|}
\hline $\begin{array}{c}\text { Number of } \\
\text { individuals }\end{array}$ & Order & Family & Genus & $\begin{array}{c}\text { Tolerance } \\
\text { quotient }\end{array}$ \\
\hline 1 & Odonata & Libellulidae & & 72 \\
\hline 2 & Trichoptera & Limnephilidae & & 108 \\
\hline 1 & Diptera & Chironomidae & Type G & 108 \\
\hline 5 & Diptera & Chironomidae & Type N & 108 \\
\hline 3 & Diptera & Chironomidae & pupae & 108 \\
\hline 63 & Diptera & Culicidae & Culiseta & 108 \\
\hline 5 & Diptera & Culicidae & Culiseta pupae & 108 \\
\hline
\end{tabular}

\section{Biodiversity}

Number of taxa $=5$

Number of individuals $=80$

Wilhm's biodiversity index $=0.91$

\section{Community Tolerance Quotient}

The CTQ was 108 . Shutting off the 128128 outfall has eliminated all but the hardiest aquatic invertebrates from the drainage. Over $96 \%$ of the invertebrates collected are flies, a group known for its rapid colonization of poor quality habitats. Eighty-five percent of the invertebrates were mosquito larvae or pupae. 


\subsubsection{Outfall 02A007, Building 16-560, 26 July 1995}

Hydrology: A steady discharge flowed from the pipe, and surface water extended for approximately $800 \mathrm{~m}$. Immediately below the point of discharge and extending for approximately $20 \mathrm{~m}$, the gravel and cobble substrate was covered with a thick red-brown algae. As the algae disappeared, the channel became more deeply incised $(0.75 \mathrm{~m})$ with a silty substrate whose smell indicated anaerobic conditions. At approximately $150 \mathrm{~m}$, the channel became a shallow ditch interspersed with mud flats before the surface water disappeared.

Wildlife use: Heavy, with elk scat, tracks in the outfall channel, and bedding along the lower channel. Signs of wildlife use were not noted for approximately $200 \mathrm{~m}$ below the outfall pipe, indicating that water above this point is not utilized by elk. It is unclear how much of the outfall water is suitable for large mammal use.

Vegetation: The surrounding upland areas are dominated by ponderosa pine (Pinus ponderosa) and Gambel's oak (Quercus gambelii). Our vegetation survey began at the outfall discharge and extended until the surface water disappeared. Much of the outfall channel is surrounded by open grassy meadows. The abundance of Sitanion hysterix indicates that much of the watercourse has been previously disturbed.

Discontinuous areas along the outfall channel contain plants associated with wetlands. Three species occurring below Outfall 02A007 are classified as obligate or facultative wetlands plants:

Eleocharis sp. - obligate wetlands

Juncus interior - facultative wetlands

Juncus baltica - facultative wetlands

These plants occur along the watercourse and in a lower wet meadow area that has been heavily used for elk bedding. The total area that could be considered as wetlands is less than 0.25 acre. 


\begin{tabular}{|c|c|c|}
\hline Scientific name & Common name & $\begin{array}{c}\text { Abundance } \\
\text { ranking } \\
\end{array}$ \\
\hline \multicolumn{3}{|c|}{ section approximately $150 \mathrm{~m}$ long } \\
\hline Agropyron smithii & Western wheatgrass & 4 \\
\hline Polygonum sp. & Smartweed & 4 \\
\hline Carex nebraskensis & Nebraska sedge & 3 \\
\hline Sitanion hysterix & Squirreltail & 3 \\
\hline Quercus gambelii & Gambel's oak & 5 \\
\hline Conyza canadensis & Horseweed & 4 \\
\hline Vigueria sp. & Golden-eye & 5 \\
\hline \multicolumn{3}{|c|}{ section approximately $280 \mathrm{~m}$} \\
\hline Sitanion hysterix & Squirreltail & 1 \\
\hline Poa fendleriana & Mutton grass & 2 \\
\hline Agropyron smithii & Western wheatgrass & 4 \\
\hline Eleocharis sp. & Spike-rush & 1 \\
\hline Bromus anomalus & Nodding brome & 5 \\
\hline \multicolumn{3}{|c|}{ section approximately $\mathbf{3 8 0} \mathrm{m}$} \\
\hline Sitanion hysterix & Squirreltail & 2 \\
\hline Poa fendleriana & Mutton grass & 4 \\
\hline Phleum praetensis & Timothy grass & 4 \\
\hline Agropyron smithii & Western wheatgrass & 5 \\
\hline Juncus baltica & Baltic rush & 3 \\
\hline Juncus interior & Inland rush & 4 \\
\hline Eleocharis & Spike-rush & 3 \\
\hline \multicolumn{3}{|c|}{ section approximately $150 \mathrm{~m}$} \\
\hline Poa fendleriana & Mutton grass & 2 \\
\hline Agropyron smithii & Western wheatgrass & 5 \\
\hline Sitanion hysterix & Squirreltail & 4 \\
\hline Juncus interior & Inland juncus & 2 \\
\hline
\end{tabular}


Physico-chemical parameters: At $50^{\circ} \mathrm{C}, 3.90 \mathrm{mg} / \mathrm{l}$ of dissolved oxygen represents $73 \%$ saturation.

\begin{tabular}{|c|c|c|c|c|}
\hline Measurement & Trial 1 & Trial 2 & Trial 3 & Average \\
\hline $\mathbf{p H}$ & 7.05 & 7.0 & 7.0 & 7.0 \\
\hline $\begin{array}{c}\text { Temperature } \\
\text { (degrees } \\
\text { Celsius) }\end{array}$ & 49.8 & 49.8 & 49.8 & 49.8 \\
\hline $\begin{array}{c}\text { Conductivity } \\
(\mu \text { mhos/cm) }\end{array}$ & 550 & 549 & 550 & 550 \\
\hline $\begin{array}{c}\text { Dissolved } \\
\text { oxygen (mg/l) }\end{array}$ & 3.90 & 3.90 & 3.90 & 3.90 \\
\hline
\end{tabular}

Undoubtedly, the high water temperatures influence adjacent vegetation and wildlife use. High levels of sulfites and $\mathrm{pH}$ fluctuations have been previously recorded here.

Aquatic invertebrates: Two aquatic invertebrate samples were collected below Outfall 02A007. The first sample was a composite from various habitats to the west of the paved road, and the second sample was a composite from various habitats to the east of the paved road. 


\section{Upper Sample \\ Taxa composition}

Despite compositing, this sample is remarkably depauperate, perhaps due to the heated water.

\begin{tabular}{|c|c|c|c|c|}
\hline $\begin{array}{c}\text { Number of } \\
\text { individuals }\end{array}$ & Order & Family & Genus & $\begin{array}{c}\text { Tolerance } \\
\text { quotient }\end{array}$ \\
\hline 1 & Diptera & Tipulidae & & 72 \\
\hline 1 & Diptera & Chironomidae & type P & 108 \\
\hline
\end{tabular}

\section{Biodiversity}

Number of taxa $=2$

Number of individuals $=2$

Wilhm's biodiversity index is intended to be used in the analysis of communities and not for samples containing only two individuals. In this case, the presence of a single individual changes the index value from 0 to 1.44 .

\section{Community Tolerance Quotient}

The CTQ is a measure of community tolerances and is not intended to be used to analyze a sample consisting of only two individuals. In this case, the presence of a single individual changes the CTQ from 108 to 90. 


\section{Lower sample \\ Taxa composition}

In addition to the invertebrates listed below, we collected 1 tadpole. This sample resembles that of better outfalls in the area, a striking contrast to the sample collected in the upper drainage.

\begin{tabular}{|c|c|c|c|c|}
\hline $\begin{array}{l}\text { Number of } \\
\text { individuals }\end{array}$ & Order & Family & Genus & $\begin{array}{r}\text { Tolerance } \\
\text { quotient }\end{array}$ \\
\hline 2 & Oligochaeta & Naididae & & 108 \\
\hline 42 & Ephemeroptera & Baetidae & Callibaetis & 72 \\
\hline 16 & Hemiptera & Corixidae & & 108 \\
\hline 1 & Odonata & Coenagrionidae & Enallagma & 72 \\
\hline 2 & Coleoptera & Dytiscidae & & 72 \\
\hline 3 & Coleoptera & $\begin{array}{c}\text { Dytiscidae } \\
\text { adults }\end{array}$ & & 72 \\
\hline 2 & Coleoptera & Hydrophilidae & & 72 \\
\hline 3 & Coleoptera & Haliplidae & Peltodytes & 54 \\
\hline 3 & Diptera & Chironomidae & type $\mathrm{P}$ & 108 \\
\hline 10 & Diptera & Chironomidae & type $G$ & 108 \\
\hline 26 & Diptera & Chironomidae & type $O$ & 108 \\
\hline 2 & Diptera & $\begin{array}{c}\text { Chironomidae } \\
\text { pupae }\end{array}$ & & 108 \\
\hline 2 & Diptera & Culicidae & Culex & 108 \\
\hline 19 & Diptera & Simulidae & Simulium & 108 \\
\hline 3 & Diptera & Tabanidae & Chrysops & 108 \\
\hline 1 & Diptera & $\begin{array}{c}\text { unindentifiable } \\
\text { pupa }\end{array}$ & & \\
\hline
\end{tabular}




\section{Biodiversity}

Number of taxa $=13$

Number of individuals $=137$

Wilhm's biodiversity index $=2.44$

The biodiversity value is one of the highest recorded for OU 1082 outfalls.

\section{Community Tolerance Quotient}

The CTQ was 94, with $61 \%$ of the individuals having a tolerance quotient of 108. This CTQ is one of the lower values for OU 1082 outfalls, indicating that some of the taxa present require moderately stable conditions. 


\subsubsection{Outfall 03A060, Building 16-430, 13 October 1994}

Hydrology: A small amount of standing water.

Wildlife use: Moderate, with elk scat and bedding. The willows had been grazed, probably by elk.

Vegetation: Surrounding area dominated by ponderosa pine and Gambel's oak with an understory of little bluestem, wormwood, and mountain muhly. Wetlands area was dominated by willows and occupied less than 0.1 acre. Vegetation surveyed along the drainage channel is shown in the following table.

\begin{tabular}{|l|l|c|}
\hline \multicolumn{1}{|c|}{ Scientific name } & \multicolumn{1}{c|}{ Common name } & $\begin{array}{c}\text { Abundance } \\
\text { ranking }\end{array}$ \\
\hline Typha latifolia & Cattail & 2 \\
\hline Salix sp. & Willow & 2 \\
\hline Agrostis alba & Redtop & 3 \\
\hline Elymus canadensis & Canadian wildrye & 3 \\
\hline Juncus sp. & Rush & 3 \\
\hline Verbascum thapsus & Mullein & 5 \\
\hline
\end{tabular}

Physico-chemical parameters: The low $\mathrm{pH}$ and conductivity values are probably due to sampling in standing water.

\begin{tabular}{|c|c|c|c|c|}
\hline Measurement & Trial 1 & Trial 2 & Trial 3 & Average \\
\hline pH & 6.2 & 6.2 & 6.2 & 6.2 \\
\hline $\begin{array}{c}\text { Temperature } \\
\text { (degrees } \\
\text { Celsius) }\end{array}$ & 19.0 & 19.5 & 19.5 & 19.3 \\
\hline $\begin{array}{c}\text { Conductivity } \\
(\mu \mathrm{mhos} / \mathrm{cm})\end{array}$ & 51 & 34 & 38 & 41 \\
\hline
\end{tabular}


Aquatic invertebrates: Sample taken from standing water.

Taxa composition

\begin{tabular}{|c|c|c|c|c|}
\hline $\begin{array}{c}\text { Number of } \\
\text { individuals }\end{array}$ & Order & Family & Genus & $\begin{array}{c}\text { Tolerance } \\
\text { quotient }\end{array}$ \\
\hline 3 & Annelida & Lubriculidae & & 108 \\
\hline
\end{tabular}

\section{Biodiversity}

Number of taxa $=1$

Number of individuals $=3$

Wilhm's biodiversity index $=0$

With only a single aquatic taxon, there is no biological diversity.

\section{Community Tolerance Quotient}

Because only three individuals were collected, the CTQ was not computed. 


\subsubsection{Outfall 03A060, Building 16-430, 5 July 1995}

Hydrology: Very small (less than $2 \mathrm{ft}^{2}$ ) and shallow ( 2 in) pool at point of discharge. No flow in drainage.

Wildlife use: Moderate, with some elk scat, tracks, and bedding in rushes. Some willows had been browsed. The willows behind building $16-430$ have been cut to ease environmental restoration sampling. The remaining willows are doing poorly.

Vegetation: Done previously.

Physico-chemical parameters: None taken due to lack of flow.

Aquatic invertebrates: None collected due to lack of flow and standing water. 


\subsubsection{Outfalls 04A157 and 05A072, Building 16-460, 29 June 1995}

Hydrology: A slight surface flow continued for approximately $1000 \mathrm{ft}$. The water was 2-4 in. deep along most of the channel and not stagnant.

Wildlife use: Moderate to high, with elk tacks and scat. The adjacent meadow contained patches of inland rush which had been heavily used for grazing and bedding.

Vegetation: The upland community was dominated by Gambel's oak and ponderosa pine.

\begin{tabular}{|l|l|c|}
\hline \multicolumn{1}{|c|}{ Scientific name } & \multicolumn{1}{|c|}{ Common name } & $\begin{array}{c}\text { Abundance } \\
\text { ranking }\end{array}$ \\
\hline Typha latifolia & Cattail & 2 \\
\hline Agrostis alba & Redtop & 2 \\
\hline Eleocharis & Spike-rush & 3 \\
\hline Veronica peregrinas & Purslane speedwell & 3 \\
\hline Juncus interior & Inland rush & 3 \\
\hline Carex sp. & Sedge & 4 \\
\hline Erigeron divergens & Fleabane daisy & 4 \\
\hline Equisetum arvense & Meadow horsetail & 4 \\
\hline Bromus sp. & Bromegrass & 5 \\
\hline Poa fendleriana & Mutton grass & 5 \\
\hline Bromus anomalus & Nodding brome & 5 \\
\hline Rumex crispus & Curlyleaf dock & 5 \\
\hline
\end{tabular}


Physico-chemical parameters: The low dissolved oxygen readings are due to the elevated water temperature. At $26.1^{\circ} \mathrm{C}, 5.9 \mathrm{mg} / \mathrm{l}$ oxygen represents $94 \%$ saturation.

\begin{tabular}{|c|c|c|c|c|}
\hline Measurement & Trial 1 & Trial 2 & Trial 3 & Average \\
\hline $\begin{array}{c}\text { Dissolved } \\
\text { oxygen (mg/1) }\end{array}$ & 5.9 & 5.9 & 5.9 & 5.9 \\
\hline pH & 8.2 & 8.2 & 8.2 & 8.2 \\
\hline $\begin{array}{c}\text { Temperature } \\
\text { (degrees } \\
\text { Celsius) }\end{array}$ & 26.2 & 26.1 & 26.1 & 26.1 \\
\hline $\begin{array}{c}\text { Conductivity } \\
(\mu \text { mhos/cm) }\end{array}$ & 175 & 175 & 175 & 175 \\
\hline
\end{tabular}

Aquatic invertebrates: In addition to the invertebrates listed below, our sample contained one tadpole.

Taxa composition

\begin{tabular}{|c|c|c|c|c|}
\hline $\begin{array}{c}\text { Number of } \\
\text { individuals }\end{array}$ & Order & Family & Genus & $\begin{array}{c}\text { Tolerance } \\
\text { quotient }\end{array}$ \\
\hline 216 & Pelecypoda & Sphaeriidae & Pisidium & Not listed. \\
\hline 5 & Oligochaeta & Annelida & Lumbriculidae & 108 \\
\hline 48 & Ephemeroptera & Baetidae & Callibaetis & 72 \\
\hline 4 & Odonata & Coenagrionidae & Zoniagrion & 108 \\
\hline 39 & Coleoptera & Dytiscidae & & 72 \\
\hline 2 & Coleoptera & Dytiscidae adults & & 72 \\
\hline 1 & Diptera & Tabanidae & Chrysops & 108 \\
\hline 1 & Diptera & Chironomidae & type H & 108 \\
\hline 279 & Diptera & Chironomidea & type A & 108 \\
\hline 10 & Diptera & Chironomidae & type G & 108 \\
\hline 1 & Diptera & Chironomidae & type PD & 108 \\
\hline 11 & Diptera & Chironomidae & & 108 \\
\hline 8 & Diptera & Culicidae & Culiseta & 108 \\
\hline 4 & Diptera & Culicidae pupae & & 108 \\
\hline 1 & Diptera & Ceratopogonidae & Bezzia & 108 \\
\hline
\end{tabular}




\section{Biodiversity}

Number of taxa $=11$

Number of individuals $=630$

Wilhm's biodiversity index $=1.55$

\section{Community Tolerance Quotient}

The CTQ was 100.3 , with $79 \%$ of the individuals having the maximum tolerance quotient of 108. Fingernail clams (genus Pisidium) comprise a large portion (34\%) of the sample, and it is unfortunate that no tolerance value is listed for them. These filter-feeding mollusks might indicate good-water quality and significantly change the CTQ. 


\subsubsection{Outfall 05A053, Building 16-410, 13 October 1994}

Hydrology: Slight flow through culvert, but quickly dispersed under willows. We saw no riffles or pools and only very shallow water over rocks.

Wildlife use: Low, with some elk pellets above the outfall.

Vegetation: The surrounding is area dominated by ponderosa pine and Gambel's oak.

The understory consisted of mountain muhly and little bluestem. The riparian area was less than 0.1 acre.

\begin{tabular}{|l|l|c|}
\hline \multicolumn{1}{|c|}{ Scientific name } & \multicolumn{1}{c|}{ Common name } & $\begin{array}{c}\text { Abundance } \\
\text { ranking }\end{array}$ \\
\hline Salix sp. & Willow & 1 \\
\hline Rubus srtigosus & Arizona red raspberry & 2 \\
\hline Juncus sp. & Rush & 2 \\
\hline Rosa woodsii & Wild rose & 3 \\
\hline Andropogon scoparius & Little bluestem & 4 \\
\hline Eupatorium herbaceum & Throughwort & 5 \\
\hline Ribes inerme & Whitestem gooseberry & 5 \\
\hline
\end{tabular}

Physico-chemical parameters: At this water temperature, the dissolved oxygen reading represents $90 \%$ saturation.

\begin{tabular}{|c|c|c|c|c|}
\hline Measurement & Trial 1 & Trial 2 & Trial 3 & Average \\
\hline $\begin{array}{c}\text { Dissolved } \\
\text { oxygen (mg/l) }\end{array}$ & 7.2 & 7.2 & 7.0 & 7.1 \\
\hline pH & 7.6 & 7.5 & 7.7 & 7.6 \\
\hline $\begin{array}{c}\text { Temperature } \\
\text { (degrees } \\
\text { Celsius) }\end{array}$ & 15.8 & 15.2 & 15.2 & 15.4 \\
\hline $\begin{array}{c}\text { Conductivity } \\
(\mu \text { mhos/cm) }\end{array}$ & 211 & 168 & 166 & 182 \\
\hline
\end{tabular}


Aquatic invertebrates: Only two aquatic invertebrates were collected, both stresstolerant fly larvae.

Taxa composition

\begin{tabular}{|c|c|c|c|c|}
\hline $\begin{array}{c}\text { Number of } \\
\text { individuals }\end{array}$ & Order & Family & Genus & $\begin{array}{c}\text { Tolerance } \\
\text { quotient }\end{array}$ \\
\hline 1 & Diptera & Chironomidae & Type A & 108 \\
\hline 1 & Diptera & Tipulidae & Antocha & 72 \\
\hline
\end{tabular}

\section{Biodiversity}

Number of $\operatorname{tax} a=2$

Number of individuals $=2$

Wilhm's biodiversity index $=1.44$

\section{Community Tolerance Quotient}

Because only two individuals were collected, the CTQ, a measure of an entire aquatic community, was not computed. 


\subsubsection{Outfall 05A053, Building 16-410, 29 June 1995}

Hydrology: The discharge pipe carries effluent to the steep edge of the canyon. There is a slight flow, but it is inaccessible due to thick vegetation and the steep slopes.

Approximately 50 yards below the pipe, open water runs over the rock surface. The trickle of water here pops up from the hillside and may not accurately represent the outfall.

Wildlife use: Low, with a single elk track and some elk scat by the water. Elk scat was observed above, but little sign was seen near the open water.

Vegetation: Done previously.

Physico-chemical parameters: None taken due to lack of flow.

\section{Aquatic invertebrates:}

Taxa composition

\begin{tabular}{|c|c|c|c|c|}
\hline $\begin{array}{c}\text { Number of } \\
\text { individuals }\end{array}$ & Order & Family & Genus & $\begin{array}{c}\text { Tolerance } \\
\text { quotient }\end{array}$ \\
\hline 12 & Ephemeroptera & Baetidae & Baetis & 72 \\
\hline 1 & Odonata & Coenagrionidae & Argia & 108 \\
\hline 3 & Trichoptera & Limnephilidae & Hesperophylax & 108 \\
\hline 2 & Diptera & Psychodidae & Pericoma & 36 \\
\hline 5 & Diptera & Tipulidae & Pedicia & 72 \\
\hline 1 & Diptera & Muscidae & Limnophora & 108 \\
\hline 6 & Diptera & Chironomidae & Type G & 108 \\
\hline 2 & Diptera & Chironomidae & pupae, Type G & 108 \\
\hline 2 & Diptera & Chironomidae & Type L & 108 \\
\hline
\end{tabular}




\section{Biodiversity}

Number of taxa $=8$

Number of individuals $=34$

Wilhm's biodiversity index $=1.98$

The compositing of samples from three separate pools probably also contributed to the high diversity value.

\section{Community Tolerance Quotient}

The CTQ was 85.8. The presence of two cranefly larvae in the genus Pedicia indicators of good-water can survive, at least for a short time, in this outfall. 


\subsubsection{Outfall 05A054 (Fish Ladder), Building 16-340, 1 July 1994}

Hydrology: Slight flow through the "fish ladder," but the water becomes discontinuous soon after reaching the ground.

Physico-chemical parameters: All measurements were made in standing pools.

\begin{tabular}{|c|c|c|c|c|}
\hline Measurement & Trial 1 & Trial 2 & Trial 3 & Average \\
\hline $\mathbf{p H}$ & 8.2 & 7.9 & 7.6 & 7.9 \\
\hline $\begin{array}{c}\text { Temperature } \\
\text { (degrees } \\
\text { Celsius) }\end{array}$ & 19.5 & 18.5 & 18.3 & 18.8 \\
\hline $\begin{array}{c}\text { Conductivity } \\
(\mu \text { mhos/cm) }\end{array}$ & 140 & 142 & 142 & 141 \\
\hline
\end{tabular}

Aquatic invertebrates: Samples taken from three standing pools. In addition to the aquatic invertebrates listed below, we collected three tadpoles.

Taxa composition

\begin{tabular}{|c|c|c|c|c|}
\hline $\begin{array}{c}\text { Number of } \\
\text { individuals }\end{array}$ & Order & Family & Genus & $\begin{array}{c}\text { Tolerance } \\
\text { quotient }\end{array}$ \\
\hline 10 & Pelecypoda & Sphaeriidae & Pisidium & Not listed. \\
\hline 1 & Ephemeroptera & Baetidae & Baetis & 72 \\
\hline 4 & Odonata & Lestidae & Archilestes & 108 \\
\hline 2 & Odonata & Coenagrionidae & Ishnura & 72 \\
\hline 1 & Odonata & Aeshnidae & Anax & 72 \\
\hline 4 & Hemiptera & Gerridae & Gerris & 72 \\
\hline 5 & Hemiptera & Gerridae & Trepobates & 72 \\
\hline 4 & Diptera & Chironomidae & Type A & 108 \\
\hline 3 & Diptera & Chironomidae & Type G & 108 \\
\hline 9 & Diptera & Culicidae & Culex & 108 \\
\hline 1 & Diptera & Empididae & & 108 \\
\hline
\end{tabular}




\section{Biodiversity}

Number of taxa $=11$

Number of individuals $=44$

Wilhm's biodiversity index $=2.64$

The compositing of samples from three separate pools probably also contributed to the high diversity value.

\section{Community Tolerance Quotient}

The CTQ is 94 ,with $48 \%$ of the individuals having the highest tolerance quotient possible of 108 . 


\subsubsection{Outfall 05A054 (Fish ladder), Building 16-340, 22 June 1995}

Hydrology: A slight flow was noted on the "fish ladder," but there was no surface flow on the ground. The upper channel was wet, and stagnant water was present in some lower pools.

Wildlife use: Moderate to high. We saw an elk and a clump of hair in the immediate area and noted many tracks and scat.

Vegetation: Done previously.

Physico-chemical parameters: None taken due to lack of flow.

Aquatic invertebrates: The lower pools were sampled. In addition, to the invertebrates listed below, EST collected 46 tadpoles.

Taxa composition

\begin{tabular}{|c|c|c|c|c|}
\hline $\begin{array}{c}\text { Number of } \\
\text { individuals }\end{array}$ & Order & Family & Genus & $\begin{array}{c}\text { Tolerance } \\
\text { quotient }\end{array}$ \\
\hline 98 & Pelecypoda & Sphaeriidae & Pisidium & Not listed. \\
\hline 4 & Oligochaeta & Lumbriculidae & & 108 \\
\hline 3 & Odonata & Coenagrionidae & Enallagma? & 72 \\
\hline 3 & Trichoptera & Limnephilidae & Hesperophylax & 108 \\
\hline 3 & Coleoptera & Dytiscidae & & 72 \\
\hline 1 & Coleoptera & Dytiscidae adult & & 72 \\
\hline 67 & Diptera & Chironomidae & Type G & 108 \\
\hline 4 & Diptera & Chironomidae & Type O & 108 \\
\hline 6 & Diptera & Chironomidae & Type K & 108 \\
\hline 4 & Diptera & Chironomidae & & 108 \\
\hline & & pupae & & \\
\hline
\end{tabular}




\section{Biodiversity}

Number of taxa $=8$

Number of individuals $=193$

Wilhm's biodiversity index $=1.33$

\section{Community Tolerance Quotient}

The CTQ was 106.7. Fingernail clams (genus Pisidium) comprise a large portion $(34 \%)$ of the sample, and it is unfortunate that no tolerance value is listed for them. These filter-feeding mollusks might indicate good-water quality and significantly change the CTQ. 


\subsubsection{Outfall 05A056, Building 16-260, 29 June 1995}

Hydrology: A slight trickle was present at the outfall discharge pipe, but the water is mostly stagnant. The channel was muddy, approximately $4 \mathrm{ft}$ wide, and ran for approximately $250 \mathrm{ft}$.

Wildlife use: Low, with some elk tracks and nearby elk scat.

Vegetation: The upland community was dominated by Gambel's oak and ponderosa pine. EST surveyed the length of the drainage but found few plants in the muddy flats.

\begin{tabular}{|l|l|c|}
\hline \multicolumn{1}{|c|}{ Scientific name } & \multicolumn{1}{|c|}{ Common name } & $\begin{array}{c}\text { Abundance } \\
\text { ranking }\end{array}$ \\
\hline Koelaria cristata & Junegrass & 5 \\
\hline Agropyron repens & Quackgrass & 5 \\
\hline
\end{tabular}

Physico-chemical parameters: None were taken due to absence of flowing water. Aquatic invertebrates: None were collected. 


\subsubsection{Outfall 05A058, Buildings in the 16-300 line, 22 June 1995}

Hydrology: A slight flow near the discharge pipe, but the water disappears after approximately $90 \mathrm{ft}$. The riparian zone is approximately $4 \mathrm{ft}$ wide and a side channel apparently contributes to the flow at times.

Wildlife use: Moderate, with some elk hair and scat observed.

Vegetation: The upland community was dominated by ponderosa pine and Gambel's oak.

\begin{tabular}{|l|l|c|}
\hline \multicolumn{1}{|c|}{ Scientific name } & \multicolumn{1}{c|}{ Common name } & $\begin{array}{c}\text { Abundance } \\
\text { ranking }\end{array}$ \\
\hline Agrostis alba & Redtop & 2 \\
\hline Poa pratensis & Kentucky bluegrass & 2 \\
\hline Eleocharis sp. & Spike-rush & 2 \\
\hline Prunella vulgaris & Healall & 3 \\
\hline Poa fendleriana & Mutton grass & 4 \\
\hline Rumex crispus & Curlyleaf dock & 4 \\
\hline Circium sp. & Thistle & 5 \\
\hline Typha latifolia & Cattail & 5 \\
\hline
\end{tabular}

Physico-chemical parameters: At this water temperature, the dissolved oxygen reading represents $103 \%$ saturation.

\begin{tabular}{|c|c|c|c|c|}
\hline Measurement & Trial 1 & Trial 2 & Trial 3 & Average \\
\hline $\begin{array}{c}\text { Dissolved } \\
\text { oxygen (mg/I) }\end{array}$ & 7.95 & 7.95 & 7.95 & 7.95 \\
\hline $\begin{array}{c}\text { Temperature } \\
\text { (degrees } \\
\text { Celsius) }\end{array}$ & 16.1 & 16.2 & 16.2 & 16.2 \\
\hline $\begin{array}{c}\text { Conductivity } \\
(\mu \text { mhos/cm) }\end{array}$ & 157 & 156 & 156 & 156 \\
\hline pH & 7.9 & 7.9 & 7.9 & 7.9 \\
\hline
\end{tabular}


Aquatic invertebrates:

Taxa composition

\begin{tabular}{|c|c|c|c|c|}
\hline $\begin{array}{c}\text { Number of } \\
\text { individuals }\end{array}$ & $\begin{array}{c}\text { Order } \\
(\text { Phylum })\end{array}$ & Family & Genus & $\begin{array}{c}\text { Tolerance } \\
\text { quotient }\end{array}$ \\
\hline 7 & Odonata & Coenagrionidae & Argia & 108 \\
\hline 37 & Diptera & Chironomidae & Type O & 108 \\
\hline 1 & Diptera & Chironomidae & Type J & 108 \\
\hline 10 & Diptera & $\begin{array}{c}\text { Chironomidae } \\
\text { pupae }\end{array}$ & Type PB & 108 \\
\hline
\end{tabular}

\section{Biodiversity}

Number of taxa $=3$

Number of individuals $=55$

Wilhm's biodiversity index $=0.50$

\section{Community Tolerance Quotient}

The CTQ was 108, the highest possible value. 


\subsubsection{Outfall 05A066, Building 9-A, 16 November 1994}

Hydrology: Minimal flow, possibly due to runoff, extended for approximately $30 \mathrm{ft}$ and was no deeper than 3 in. The drainage does not appear to have held much water recently. Wildlife use: Low, with no signs of wildlife usage detected.

Vegetation: The surrounding vegetation was dominated by ponderosa pine. EST surveyed approximately $120 \mathrm{ft}$ of vegetation along the predominantly dry water course.

\begin{tabular}{|l|l|c|}
\hline \multicolumn{1}{|c|}{ Scientific name } & \multicolumn{1}{|c|}{ Common name } & $\begin{array}{c}\text { Abundance } \\
\text { ranking }\end{array}$ \\
\hline Rosa & Wild rose & 3 \\
\hline Elymus canadensis & Canadian wildrye & 3 \\
\hline Agrostis alba & Redtop & 3 \\
\hline Bromus anomalus & Nodding brome & 4 \\
\hline Andropogon scoparius & Little bluestem & 4 \\
\hline Unknown grass \#1 & & 4 \\
\hline Geranium richardsonii & Richardson's geranium & 5 \\
\hline Sporobolus contractus & Spike dropseed & 5 \\
\hline Antennaria parvifolia & Pussytoes & 5 \\
\hline
\end{tabular}

Physico-chemical parameters: The dissolved oxygen readings were unusually low (45\% saturation). Measurements of $\mathrm{pH}$ were not taken.

\begin{tabular}{|c|c|c|c|c|}
\hline Measurement & Trial 1 & Trial 2 & Trial 3 & Average \\
\hline $\begin{array}{c}\text { Dissolved } \\
\text { oxygen (mg/) }\end{array}$ & 3.9 & 4.1 & 4.0 & 4.0 \\
\hline $\begin{array}{c}\text { Temperature } \\
\text { (degrees } \\
\text { Celsius) }\end{array}$ & 10.0 & 10.0 & 10.0 & 10.0 \\
\hline $\begin{array}{c}\text { Conductivity } \\
(\mu \mathrm{mhos} / \mathrm{cm})\end{array}$ & 163 & 165 & 167 & 165 \\
\hline
\end{tabular}

Aquatic invertebrates: No aquatic organisms observed. Due to the lack of water and the fact that it had been previously frozen, an aquatic invertebrate sample was not collected. 


\subsubsection{Outfall 05A066, Building 9-A, 5 July 1995}

Hydrology: Approximately 150 yards of slight flow.

Wildlife use: Low, with some elk scat.

Vegetation: Done previously.

Physico-chemical parameters: The previously recorded (16 November 1994) low oxygen saturation of $45 \%$ was obtained again.

\begin{tabular}{|c|c|c|c|c|}
\hline Measurement & Trial 1 & Trial 2 & Trial 3 & Average \\
\hline $\begin{array}{c}\text { Dissolved } \\
\text { oxygen (mg/) }\end{array}$ & 3.5 & 3.45 & 3.5 & 3.5 \\
\hline $\begin{array}{c}\text { Temperature } \\
\text { (degrees } \\
\text { Celsius) }\end{array}$ & 17 & 17 & 17 & 17 \\
\hline $\begin{array}{c}\text { Conductivity } \\
(\mu \text { mhos/cm) }\end{array}$ & 201 & 202 & 202 & 202 \\
\hline
\end{tabular}

Aquatic invertebrates:

Taxa composition

\begin{tabular}{|c|c|c|c|c|}
\hline $\begin{array}{c}\text { Number of } \\
\text { individuals }\end{array}$ & $\begin{array}{c}\text { Order } \\
(\text { Phylum })\end{array}$ & Family & Genus & $\begin{array}{c}\text { Tolerance } \\
\text { quotient }\end{array}$ \\
\hline 1 & Annelida & Lumbriculidae & & 108 \\
\hline 1 & Coleoptera & Dytisicdae & & 72 \\
\hline 2 & Diptera & Chironomidae & Type O & 108 \\
\hline 3 & Diptera & Chironomidae & Type K & 108 \\
\hline 3 & Diptera & Chironomidae & Type J & 108 \\
\hline 1 & Diptera & Chironomidae & pupa & 108 \\
\hline
\end{tabular}




\section{Biodiversity}

Number of $\operatorname{tax} a=5$

Number of individuals $=11$

Wilhm's biodiversity index $=1.67$

\section{Community Tolerance Quotient}

The CTQ of 105 indicates an extremely disturbed community, probably due to sporadic flow. 


\subsubsection{Outfall 05A067, Building 9-B, 16 November 1994}

Hydrology: Dry, with some standing pools that were probably due to recent storm runoff. When running, this outfall empties into the same drainage as 05A066, but it apparently has not had much recent flow.

Wildlife use: Low, with few signs of animal activity. We saw some elk scat, one set of elk tracks, and one set of coyote tracks.

Vegetation: The surrounding area is dominated by ponderosa pine. The riparian vegetation was surveyed to 100 yards below the point of discharge.

\begin{tabular}{|l|l|c|}
\hline \multicolumn{1}{|c|}{ Scientific name } & \multicolumn{1}{|c|}{ Common name } & $\begin{array}{c}\text { Abundance } \\
\text { ranking }\end{array}$ \\
\hline Agrostis alba & Redtop & 1 \\
\hline Unknown grass \#1 & & 2 \\
\hline Poa fendleriana & Mutton grass & 4 \\
\hline Andropogon scoparius & Little bluestem & 5 \\
\hline
\end{tabular}

Physico-chemical parameters: None taken due to lack of running water. Aquatic invertebrates: None collected due to lack of water and having been previously frozen. 


\subsubsection{Outfall 05A067, Building 9-B, 5 July 1995}

Hydrology: Dry.

Wildlife use: Low, with elk bedding in channel.

Vegetation: Grasses and rushes occurred in the channel immediately below the outfall.

Approximately $200 \mathrm{ft}$ below the outfall, a grassy meadow in the lower channel had

Nebraska sedge (Carex nebraskensis) as a dominant.

Physico-chemical parameters: None taken due to lack of flow.

Aquatic invertebrates: None collected due to lack of flow. 


\subsubsection{Outfall 05A068, Building 9-48, 16 November 1994}

Hydrology: Dry.

Wildlife use: Moderate, with ungulate bedding and elk scat.

Vegetation: The surrounding area is dominated by ponderosa pine and Gambel's oak.

The vegetation was surveyed to the end of the drainage, approximately $150 \mathrm{ft}$.

\begin{tabular}{|l|l|c|}
\hline \multicolumn{1}{|c|}{ Scientific name } & \multicolumn{1}{|c|}{ Common name } & $\begin{array}{c}\text { Abundance } \\
\text { ranking }\end{array}$ \\
\hline Agrostis alba & Redtop & 1 \\
\hline Antennaria parviflora & Pussytoes & 3 \\
\hline Muhlenbergia montana & Mountain muhly & 4 \\
\hline Unknown grass \#2 & & 4 \\
\hline Elymus canadensis & Canadian wildrye & 5 \\
\hline
\end{tabular}

Physico-chemical parameters: None taken due to lack of water.

Aquatic invertebrates: None collected due to lack of water. 


\subsubsection{Outfalls 05A069 (K Site), Building 11-50, 13 October 1994}

Hydrology: All outfalls dry with no evidence of recent flow. A well-defined stream channel fed approximately one acre of cattails interspersed with areas of thick grasses. We found no running or standing water, and all cattails were brown.

Wildlife use: Moderate, with elk pellets, tracks, and bedding. In summer 1994, EST found canyon tree frogs and many-lined skinks here.

Vegetation: The surrounding area is dominated by ponderosa pine and scattered Gambel's oak. The understory was dominated by little bluestem and mountain muhly. We surveyed the cattails and grassy areas within the drainage.

\begin{tabular}{|l|l|c|}
\hline \multicolumn{1}{|c|}{ Scientific name } & \multicolumn{1}{|c|}{ Common name } & $\begin{array}{c}\text { Abundance } \\
\text { ranking }\end{array}$ \\
\hline Typha latifolia & Cattails & 1 \\
\hline Lycurus phleoides & Wolftail & 3 \\
\hline Muhlenbergia montana & Mountain muhly & 3 \\
\hline Elymus canadensis & Canadian wildrye & 3 \\
\hline Agrostis alba & Redtop & 3 \\
\hline Carex sp. & Sedge & 3 \\
\hline Poa fendleriana & Mutton grass & 4 \\
\hline Rosa woodsii & Wild rose & 5 \\
\hline Verbascum thapsus & Mullein & 5 \\
\hline Sitanion hystrix & Squirreltail & 5 \\
\hline Circium sp. & Thistle & 5 \\
\hline Rumex crispus & Curly dock & 5 \\
\hline
\end{tabular}

Physico-chemical parameters: None taken due to lack of water.

Aquatic invertebrates: None collected due to lack of water. 


\subsubsection{Outfalls 05A072 and 04A157, Building 16-460, 29 June 1995}

Hydrology: A slight surface flow continued for approximately $1000 \mathrm{ft}$. The water was not stagnant and had little algal growth.

Wildlife use: Moderate to high, with elk tacks and scat. The adjacent meadow contained patches of inland rush which had been heavily used for grazing and bedding.

Vegetation: The upland community was dominated by Gambel's oak and ponderosa pine.

\begin{tabular}{|l|l|c|}
\hline \multicolumn{1}{|c|}{ Scientific name } & \multicolumn{1}{c|}{ Common name } & $\begin{array}{c}\text { Abundance } \\
\text { ranking }\end{array}$ \\
\hline Typha latifolia & Cattail & 2 \\
\hline Agrostis alba & Redtop & 2 \\
\hline Eleocharis & Spike-rush & 3 \\
\hline Veronica peregrinas & Purslane speedwell & 3 \\
\hline Juncus interior & Inland rush & 3 \\
\hline Carex sp. & Sedge & 4 \\
\hline Erigeron divergens & Fleabane daisy & 4 \\
\hline Equisetum arvense & Meadow horsetail & 4 \\
\hline Bromus sp. & Bromegrass & 5 \\
\hline Poa fendleriana & Mutton grass & 5 \\
\hline Bromus anomalus & Nodding brome & 5 \\
\hline Rumex crispus & Curlyleaf dock & 5 \\
\hline
\end{tabular}


Physico-chemical parameters: The seemingly low dissolved oxygen values are due to the elevated water temperature. At $26^{\circ} \mathrm{C}, 5.9 \mathrm{mg} / \mathrm{l}$ oxygen represents $93 \%$ oxygen saturation.

\begin{tabular}{|c|c|c|c|c|}
\hline Measurement & Trial 1 & Trial 2 & Trial 3 & Average \\
\hline $\begin{array}{c}\text { Dissolved } \\
\text { oxygen (mg/l) }\end{array}$ & 5.9 & 5.9 & 5.9 & 5.9 \\
\hline pH & 8.2 & 8.2 & 8.2 & 8.2 \\
\hline $\begin{array}{c}\text { Temperature } \\
\text { (degrees } \\
\text { Celsius) }\end{array}$ & 26.2 & 26.1 & 26.1 & 26.1 \\
\hline $\begin{array}{c}\text { Conductivity } \\
(\mu \text { mhos/cm) }\end{array}$ & 175 & 175 & 175 & 175 \\
\hline
\end{tabular}

Aquatic invertebrates: In addition to the invertebrates listed below, we collected one tadpole in our sample.

Taxa composition

\begin{tabular}{|c|c|c|c|c|}
\hline $\begin{array}{c}\text { Number of } \\
\text { individuals }\end{array}$ & Order & Family & Genus & $\begin{array}{c}\text { Tolerance } \\
\text { quotient }\end{array}$ \\
\hline 216 & Pelecypoda & Sphaeriidae & Pisidium & Not listed. \\
\hline 5 & Oligochaeta & Annelida & Lumbriculidae & 108 \\
\hline 48 & Ephemeroptera & Baetidae & Callibaetis & 72 \\
\hline 4 & Odonata & Coenagrionidae & Zoniagrion & 108 \\
\hline 39 & Coleoptera & Dytiscidae & & 72 \\
\hline 2 & Coleoptera & Dytiscidae adults & & 72 \\
\hline 1 & Diptera & Tabanidae & Chrysops & 108 \\
\hline 1 & Diptera & Chironomidae & type H & 108 \\
\hline 279 & Diptera & Chironomidea & type A & 108 \\
\hline 10 & Diptera & Chironomidae & type G & 108 \\
\hline 1 & Diptera & Chironomidae & type PD & 108 \\
\hline 11 & Diptera & Chironomidae & & 108 \\
\hline 8 & Diptera & Culicidae & Culiseta & 108 \\
\hline 4 & Diptera & Culicidae pupae & & 108 \\
\hline 1 & Diptera & Ceratopogonidae & Bezzia & 108 \\
\hline
\end{tabular}




\section{Biodiversity}

Number of taxa $=11$

Number of individuals $=630$

Wilhm's biodiversity index $=1.55$

\section{Community Tolerance Quotient}

The CTQ was 100.3 , with $79 \%$ of the individuals having the maximum tolerance quotient of 108 . 


\subsection{Natural waterways within the area}

Surveys from springs and canyons in the upper Pajarito Canyon watershed are presented for comparison with the OU 1082 outfalls. These locations have been previously sampled by NMED's Agreement in Principle (AIP) personnel. AIP members have also recommended that two of these areas (Starmer's Gulch and Bulldog Spring) be used as aquatic reference sites for comparison with other Laboratory sites. Discharges from Laboratory outfalls may indirectly contribute to the total volume of water in these "natural waterways," but their contribution is assumed to be slight.

A brief description of each site is given, including such information as location, estimated stream flow, and surrounding vegetation. Physico-chemical parameters of $\mathrm{pH}$, water temperature, dissolved oxygen, and conductivity were recorded at most sites.

Collected aquatic invertebrate data were analyzed using Wilhm's biodiversity index and CTQs. Invertebrate densities were calculated at all sites where Surber sampler was used. The conditions of these waterways are discussed at greater length in the conclusions section. 


\subsubsection{Starmer's Gulch, 1 July 1994}

Ralph Ford-Schmid of the NMED's AIP and members of EST sampled three sites near Starmer's Gulch, a tributary of Pajarito Canyon in TA-9. Mr. Ford-Schmid and I evaluated the area with a Rapid Bioassessment Protocol habitat assessment (Plafkin 1989). Both of us agreed that the stream appeared to provide optimal habitat for aquatic invertebrates. The dominant trees in the area were Douglas-fir (Pseudotsuga menziesii), white fir (Abies concolor), ponderosa pine (Pinus ponderosa), and Gambel's oak (Quercus gambelii).

EST collected semi-quantitative aquatic macroinvertebrate samples with a kicknet. We sampled Starmer's Gulch, approximately $50 \mathrm{ft}$ above the confluence with Pajarito Canyon. The sample was subsampled according to the procedure described by Cross (1994). The invertebrates listed below are a composite of three subsamples with a total of 345 individuals. Number in parentheses are CTQs.

Non-insects - 11

5 Annelida, Oligochaeta (108)

2 Nematomorpha

2 Platyhelminthes, Turbellaria (108)

1 Hydracarina

Plecoptera - 43

1 Gastropoda (108)

23 Perlidae, Hesperoperla pacifica (18)

16 Chloroperlidae (24)

4 Nemouridae, Amphinemura (6)

Ephemeroptera - 82

82 Baetidae, Baetis (72)

Trichoptera - 6

2 Hydropsychidae, Hydropsyche (108)

2 Limnephilidae, Hesperophylax (108)

Diptera - 203

2 Lepidostomatidae, Lepidostoma (18)

195 Chironomidae, type I (108)

1 Chironomidae, type B (108)

6 Simulidae (108)

1 Tipulidae, Dicranota (24)

Number of taxa $=16$

Number of individuals $=345$

Wilhm's biodiversity index $=2.56$

Community tolerance quotient $=87.5$

Several good-quality indicator taxa (mostly stoneflies) were present, but $62 \%$ of the 345 individuals analyzed had CTQs of 108 (the highest possible). Density is not reported because EST used sub-sampling to evaluate the sample. 


\subsubsection{Upper Pajarito Canyon, 1 July 1994}

Ralph Ford-Schmid of the NMED's AIP and members of EST sampled three sites near Starmer's Gulch, a tributary of Pajarito Canyon in TA-9. Mr. Ford-Schmid and I evaluated the area with a Rapid Bioassessment Protocol habitat assessment (Plafkin 1989). Both of us agreed that the stream appeared to provide optimal habitat for aquatic invertebrates. The dominant trees in the area were Douglas-fir (Pseudotsuga menziesii), white fir (Abies concolor), ponderosa pine (Pinus ponderosa), and Gambel's oak (Quercus gambelii).

Physico-chemical parameters: Taken below the confluence of Starmer's Gulch and upper Pajarito Canyon. At $13.4^{\circ} \mathrm{C}, 7.2 \mathrm{mg} / \mathrm{l}$ of oxygen represents $67 \%$ saturation.

\begin{tabular}{|c|c|c|c|c|}
\hline Measurement & Trial 1 & Trial 2 & Trial 3 & Average \\
\hline $\begin{array}{c}\text { Dissolved } \\
\text { oxygen (mg/1) }\end{array}$ & 7.2 & 7.2 & 7.1 & 7.2 \\
\hline pH & 7.5 & 7.5 & 7.5 & 7.5 \\
\hline $\begin{array}{c}\text { Temperature } \\
\text { (degrees } \\
\text { Celsius) }\end{array}$ & 13.7 & 12.7 & 12.7 & 13.4 \\
\hline $\begin{array}{c}\text { Conductivity } \\
(\mu \mathbf{m h o s} / \mathbf{c m})\end{array}$ & 114 & 121 & 126 & 120 \\
\hline
\end{tabular}

EST collected semi-quantitative aquatic macroinvertebrate samples with a kicknet. Station 1 was approximately $50 \mathrm{ft}$ below the confluence of Starmer's Gulch and upper Pajarito Canyon in TA 9.; station 2 was approximately $100 \mathrm{ft}$ below the confluence. Samples were subsampled according to the procedure described by Cross (1994). Number in parentheses are tolerance quotients.

\section{Upper Pajarito Canyon, Station 1}

Non-insects - 7

6 Annelida, Oligochaeta (108)

1 Hydracarina

Plecoptera - 13

8 Perlidae, Hesperoperla pacifica (18)

4 Chloroperlidae (24)

1 Nemouridae, Amphinemura (6)

Ephemeroptera - 44

42 Baetidae, Baetis (72)

2 Siphlonuridae, Ameletus (48)

Trichoptera - 2

2 Limnephilidae, Hesperophylax (108)

Coleoptera -8

5 Elmidae, Heterlimnius corpulentus (108) 
3 Elmidae adults, Heterlimnius corpulentus (108)

Diptera - 33

22 Chironomidae A (108)

9 Simulidae (108)

2 Tipulidae, Dicranota (24)

Number of taxa $=13$

Number of individuals $=107$

Wilhm's biodiversity index $=2.57$

Community tolerance quotient $=80.1$

Several good-quality indicator taxa (mostly stoneflies) were present, and only $44 \%$ of the individuals had tolerance quotients of 108. Density is not reported because EST used sub-sampling to evaluate the sample. 
Upper Pajarito Canyon, Station 2

Non-insects - 19

10 Annelida, Oligochaeta (108)

8 Platyhelminthes, Turbellaria (108)

1 Ostracoda, Cyprididae (108)

Plecoptera - 28

15 Chloroperlidae (24)

13 Perlidae, Hesperoperla pacifica (18)

Ephemeroptera - 75

64 Baetidae, Baetis (72)

11 Siphlonuridae, Ameletus (48)

Trichoptera -7

6 Limnephilidae, Hesperophylax (108)

1 unidentifiable pupa

Coleoptera - 6

3 Elmidae, Heterlimnius corpulentus (108)

3 Elmidae adults, Heterlimnius corpulentus (108)

Diptera - 15

12 Chironomidae, Type A (108)

2 Simulidae (108)

1 Tipulidae Dicranota (24)

Number of taxa $=12$

Number of individuals $=150$

Wilhm's biodiversity index $=2.20$

Community tolerance quotient $=70.4$

Several good-quality indicator taxa (mostly stoneflies) were present, and only $44 \%$ of the individuals had tolerance quotients of 108. This site had the lowest CTQ of all sites sampled. Density is not reported because EST used sub-sampling to evaluate the sample. 


\subsubsection{Starmer's Gulch, 20 June 1995}

Stream flow was estimated at $180 \mathrm{gpm}$ using a five-gallon bucket. The dominant trees in the area were Douglas-fir (Pseudotsuga menziesii), white fir (Abies concolor), ponderosa pine (Pinus ponderosa), and Gambel's oak (Quercus gambelii).

Physico-chemical parameters: At this water temperature, the dissolved oxygen reading represents $101 \%$ oxygen saturation.

\begin{tabular}{|c|c|c|c|c|}
\hline Measurement & Trial 1 & Trial 2 & Trial 3 & Average \\
\hline $\begin{array}{c}\text { Dissolved } \\
\text { oxygen (mg/) }\end{array}$ & 8.85 & 8.65 & 8.6 & 8.70 \\
\hline pH & 7.4 & 7.3 & 7.3 & 7.3 \\
\hline $\begin{array}{c}\text { Temperature } \\
\text { (degrees } \\
\text { Celsius) }\end{array}$ & 10.8 & 11.0 & 11.0 & 10.9 \\
\hline $\begin{array}{c}\text { Conductivity } \\
(\mu \text { mhos/cm) }\end{array}$ & 184 & 186 & 189 & 186 \\
\hline
\end{tabular}

Aquatic invertebrates: EST sampled for aquatic invertebrates with a Surber sampler. The entire sample was sorted and identified, i.e. no sub-sampling occurred. The stream was heavily sedimented, and the water was milky-colored. We sampled in front of a rock wall, approximately $150 \mathrm{ft}$ above confluence with Pajarito Canyon. At the sampling site, the stream was bordered by an eastern rock wall and a western bank of horsetail

(Equisetum sp.), grasses, and rushes (Juncus sp.).

Non-insects -6

4 Annelida, Lumbriculidae (108)

2 Platyhelminthes, Turbellaria (108)

Plecoptera - 10

5 Perlidae, Hesperoperla pacifica (18)

4 Chloroperlidae (24)

1 Nemouridae, Amphinemura (6)

Ephemeroptera - 41

41 Baetidae, Baetis (72)

Trichoptera -6

2 Limnephilidae, Hesperophylax (108)

1 Hydroptilidae, Alisotrichia (108)

1 Hydropsychidae, Hydropsyche (108)

2 Lepidostomatidae, Lepidostoma (18)

Coleoptera - 1

1 Hydrophilidae

Diptera - 37

1 Simulidae, Simulium (108)

33 Chironomidae, type A (108)

2 Tipulidae, Dicranota(24)

1 unidentifiable pupa 
Number of taxa $=14$

Number of individuals $=101$

Wilhm's biodiversity index $=3.03$

Density $=1087$ aquatic invertebrates $/ \mathrm{m}^{2}$

Community tolerance quotient $=80.5$ 


\subsubsection{Upper Pajarito Canyon, 20 June 1995}

Stream flow was visually estimated to be $6-8 \mathrm{gpm}$. The dominant trees in the area were Douglas-fir (Pseudotsuga menziesii), white fir (Abies concolor), ponderosa pine (Pinus ponderosa), and Gambel's oak (Quercus gambelii).

Physico-chemical parameters: At this water temperature, the dissolved oxygen reading represents $92 \%$ saturation.

\begin{tabular}{|c|c|c|c|c|}
\hline Measurement & Trial 1 & Trial 2 & Trial 3 & Average \\
\hline $\begin{array}{c}\text { Dissolved } \\
\text { oxygen (mg/) }\end{array}$ & 7.7 & 7.7 & 7.7 & 7.7 \\
\hline $\mathbf{p H}$ & 7.3 & 7.3 & 7.3 & 7.3 \\
\hline $\begin{array}{c}\text { Temperature } \\
\text { (degrees } \\
\text { Celsius) }\end{array}$ & 12.0. & 12.2 & 12.2 & 12.1 \\
\hline $\begin{array}{c}\text { Conductivity } \\
(\mu \text { mhos/cm) }\end{array}$ & 109 & 109 & 111 & 110 \\
\hline
\end{tabular}

Aquatic invertebrates: The stream substrate was primarily dirt covered with old oak leaves. EST sampled the main channel of Pajarito Canyon approximately $20 \mathrm{yds}$. above the confluence of Starmer's Gulch with a Surber sampler. The entire sample was sorted and identified, i.e. no sub-sampling occurred.

Non-insects - 47

24 Annelida, Lumbriculidae (108)

23 Platyhelminthes, Turbellaria (108)

Plecoptera - 18

5 Perlidae, Hesperoperla pacifica (18)

12 Chloroperlidae (24)

1 Nemouridae, Malenka

Ephemeroptera - 72

34 Baetidae, Baetis (72)

14 Siphlonuridae, Ameletus (45)

19 Heptageniidae, Cinygmula (21)

5 Leptophlebiidae, Paraleptophlebia (24)

Hemiptera -2

2 Veliidae, Microvelia (72)

Trichoptera - 23

14 Limnephilidae, Hesperophylax (108)

1 Limnephilidae pupa, Hesperophylax (108)

4 Lepidostomatidae, Lepidostoma (18)

1 Leptoceridae, Oecetis? (54)

1 Hydropsychidae, Hydropsyche (108)

2 unidentifiable pupae 
Coleoptera - 37

27 Elmidae, Heterlimnius corpulentus (108)

8 Elmidae adults, Heterlimnius corpulentus (108)

Diptera - 12

2 Elmidae, Narpus (108)

4 Chironomidae, type A (108)

1 Chironomidae, type G (108)

2 Tipulidae, Dicranota (24)

5 Tipulidae (72)

Number of taxa $=20$

Number of individuals $=211$

Wilhm's biodiversity index $=3.55$

Density $=2270$ aquatic invertebrates $/ \mathrm{m}^{2}$

Community tolerance quotient $=79.9$

This sample had the highest biodiversity and density of all sites sampled. 


\subsubsection{Bulldog Spring, 20 June 1995}

Bulldog Spring is approximately 0.5 mile downstream from Starmer's Gulch. Bulldog is located in a steep side canyon containing river birch (Betula occidentalis), white fir (Abies concolor), Douglas-fir (Pseudotsuga menziesii), and ponderosa pine (Pinus ponderosa). The streambed contained large rocks and fine sediments.

Physico-chemical parameters: At this water temperature, the dissolved oxygen reading represents $99 \%$ saturation.

\begin{tabular}{|c|c|c|c|c|}
\hline Measurement & Trial 1 & Trial 2 & Trial 3 & Average \\
\hline $\begin{array}{c}\text { Dissolved } \\
\text { oxygen (mg/) }\end{array}$ & 8.05 & 7.95 & 7.90 & 7.97 \\
\hline $\mathbf{p H}$ & 7.6 & 7.6 & 7.6 & 7.6 \\
\hline $\begin{array}{c}\text { Temperature } \\
\text { (degrees } \\
\text { Celsius) }\end{array}$ & 13.9 & 14.0 & 14.0 & 14.0 \\
\hline $\begin{array}{c}\text { Conductivity } \\
(\mu \text { mhos/cm) }\end{array}$ & 199 & 200 & 201 & 200 \\
\hline
\end{tabular}

Aquatic invertebrates: EST sampled one of the few riffle areas with stacked rocks at a location approximately 75 yards above the confluence with Pajarito Canyon. A Surber sampler was used and the entire sample was sorted and identified, i.e. no sub-sampling occurred.

Non-insects - 3

3 Platyhelminthes, Turbellaria (108)

Plecoptera - 9

5 Nemouridae, Amphinemura (6)

4 Chloroperlidae (24)

Trichoptera - 68

1 Limnephilidae, Amphicosmoecus cana (18)

5 Limnephilidae, Hesperophylax (108)

54 Hydropsychidae, Hydropsyche (108)

2 Philopotamidae, Dolophilodes (24)

3 Lepidostomatidae, Lepidostoma (18)

Coleoptera - 56

3 unidentifiable pupae

39 Elmidae, Heterlimnius corpulentus (108)

16 Elmidae adults, Heterlimnius corpulentus (108)

1 Hydrophilidae, Hydrobius (72) 
Diptera - 36

19 Chironomidae, type A (108)

6 Chironomidae, type B (108)

6 Chironomidae, type C (108)

2 Chironomidae, type G (108)

1 Simulidae, Simulium (108)

2 Tipulidae, Dicranota (24)

Number of $\operatorname{tax} a=16$

Number of individuals $=172$

Wilhm's biodiversity index $=2.91$

Density $=1850$ aquatic invertebrates $/ \mathrm{m}^{2}$

Community tolerance quotient $=99.2$ 


\section{CONCLUSIONS}

The physico-chemical parameters at most outfalls fell within the normal range of natural waters in the area. Whereas outfall $05 \mathrm{~A} 066$ had only $45 \%$ oxygen saturation on two separate sampling dates (November 1994 and July 1995), all other outfalls had oxygen saturations ranging from 90 to $118 \%$. Water temperatures ranged from $10.0^{\circ} \mathrm{C}$ to $26.1^{\circ} \mathrm{C}$, except at $02 \mathrm{~A} 007$ where steam plant discharge elevated the water temperature to $49.8^{\circ} \mathrm{C}$. Considering only outfalls with flowing water, we recorded conductivity values from 41 to 761 (average $=255$ ) $\mu \mathrm{mhos} / \mathrm{cm}$. The highest conductivity value was recorded at outfall 128128 in November 1994, and if it is not figured in, the average value drops to 199 $\mu \mathrm{mhos} / \mathrm{cm}$. The $\mathrm{pH}$ readings ranged from 7.6 to 8.4 (average $=8.1$ ).

The physico-chemical parameters of natural waterways discussed in this report were all taken on 20 June 1995. Oxygen saturation ranged from 67 to $101 \%$, with an average value of $90 \%$. Water temperatures were relatively similar, from $10.9^{\circ} \mathrm{C}$ to $14.0^{\circ} \mathrm{C}$. Conductivity values ranged from 110 to 200 (average $=165$ ). The recorded $\mathrm{pH}$ values were low in comparison to other natural waterways in the area, ranging from 7.3 to 7.6 (average $=7.4$ ). Consultation with representatives of the New Mexico Environmental Department revealed that low $\mathrm{pH}$ values have been consistently recorded at these sites.

The outfalls are characterized by low biodiversity and severely stressed communities. However, the three outfalls with the greatest biodiversities (02A077 in July 1995, 05 A053 in June 1995, and 05A054 in July 1994) also had the lowest CTQs. Wilhm's biodiversity index values at the outfalls ranged from 0 to 2.64 , with an average of 1.55. This is a very low value and indicates a severely stressed community composed of a restricted number of taxa. In computing the outfall CTQ values, I omitted three samples containing less than four invertebrates each (03A060 and 05A053, both in October 1994, and $02 \mathrm{A007}$ in July 1995). CTQ values at all outfalls were very high, ranging from 85.8 to 108 , with an average of 101 . This value shows that the few taxa found in the outfalls are capable of withstanding periodic disturbance. Such communities are poorly structured and characterized by rapid colonizers of impaired habitats.

In contrast to the outfalls, the natural waterways of the area had greater densities of aquatic invertebrates, higher biodiversities, and lower CTQs. The densities of natural waterways ranged from 1087 to 2270 (average $=1736$ ) aquatic invertebrates per square meter. Although density measurements were not taken at the outfalls, they contained significantly fewer invertebrates. Wilhm's biodiversity index values ranged from 2.20 to 3.55 , with an average value of 2.80. Only two outfalls (05A054 in July 1994 and 02A007 in July 1995) had higher biodiversity values than the lowest value recorded for a natural 
waterway, indicating the natural communities are much more developed than those of the outfalls. The natural waterways had CTQs ranging from 70.4 to 99.2 . The average CTQ value of 82.9 is considerably lower than that of the averaged outfalls (102), demonstrating that the aquatic invertebrates found in the natural waterways include more good-water quality indicators.

With only four exceptions (low oxygen at 05A066 in November 1994 and July 1995, high conductivity at 128128 in November 1994, and high water temperature at 02A007 in July 1995), all physico-chemical parameters taken at the outfalls are within normal ranges. The habitat at the other outfalls could probably support well-developed aquatic communities if sufficient water was available. However, the hydrology at these outfalls is too slight and/or sporadic to support such a community in the foreseeable future.

\section{ACKNOWLEDGMENTS}

This project was supported by ESH-18 (Water Quality and Hydrology) and its group leader, Steve Rae. The study was overseen by Kathryn Bennett, team coordinator for the Ecological Studies Team of the Environmental Assessments and Resource Evaluations Group (ESH-20) of the Los Alamos National Laboratory. Field and laboratory personnel included Saul Cross (field team leader and aquatic entomologist), Dan Dunham (botanist), David Keller (ecologist), Leonard Sandoval (UGS), and Tomas Gonzalez (UGS). Saul Cross identified all aquatic macroinvertebrates, analyzed the data, and compiled the manuscript. 


\section{REFERENCES}

Bailey, M., 1995, personal communication.

Baumann, R.W., A.R. Gaufin, and R.F. Surdick, 1977, The Stoneflies (Plecoptera) of the Rocky Mountains, American Entomological Society at the Academy of Natural Sciences, Philadelphia, PA.

Cross, S.P., 1994, "A Test of Aquatic Macroinvertebrate Sub-Sampling Using a Gridded Screen," LA-UR-94-4225 (sumbitted to Archives für Hydrobiologie).

Edmunds, G.F., Jr., S.L. Jensen, and L. Berner, 1976, The Mayflies of North and Central America, University of Minnesota Press, Minneapolis, MN.

Jackson, S., and W. Davis, 1994, "Meeting the Goal of Biological Integrity in WaterResource Programs in the U. S. Environmental Protection Agency," Journal of the North American Benthological Society, 13 (4): 592-597.

Karr, J.R., 1991, "Biological Integrity: A Long-Neglected Aspect of Water Resource Management," Ecological Applications 1: 66-84.

McCafferty, W.P., 1981, Aquatic Entomology, Jones and Bartlett Publishers, Inc., Boston, MA.

Merritt, R.W., and K.W. Cummins, 1984, An Introduction to the Aquatic Insects of North America, 2nd ed., Kendall/Hunt Publishing Company, Dubuque, IA.

Pennak, R.W., 1978, Fresh-Water Invertebrates of the United States, 2nd ed., John Wiley \& Sons, New York, NY.

Plafkin, J.L., M.T. Barbour, K.D. Porter, S.K. Gross, and R.M. Hughes, Rapid Bioassessment Protocols for Use in Streams and Rivers, U. S. Environmental Protection Agency, Office of Water, EPA/440/4-89/001.

U. S. Environmental Protection Agency, 1988, "WQS Draft Framework for the Water Quality Standards Program," Office of Water, Washington, DC, 11-8-88. 
U. S. Environmental Protection Agency, 1990, "Invertebrate Field and Laboratory Methods for Evaluating the Biological Integrity of Surface Waters," Office of Research and Development, Washington, DC, EPA/600/4-90/030.

U. S. Environmental Protection Agency, 1991, "Environmental Indicators: Policies, Programs, and Success Stories," Environmental Indicators Workshop, July 17-19, 1991, Office of Policy, Planning, and Evaluation, EPA, Washington, DC.

Weber, C.I., 1973, "Biological Field and Laboratory Methods for Measuring the Quality of Surface Waters and Effluents," National Environmental Research Center, Cincinnati, $\mathrm{OH}$, PB-227-183, pp. 70-109.

Wiggins, G.B., 1977, Larvae of the North American Caddisfly Genera (Trichoptera) University of Toronto Press, Toronto, Ontario, Canada.

Wilhm, J.L., 1967, "Comparison of Some Diversity Indices Applied to Populations of Benthic Invertebrate in a Stream Receiving Organic Waste," Journal WPCF 39: 16731683.

Winget, R.N., and F.A. Magnum, 1989, Biotic Condition Index: Integrated Biological, Physical, and Chemical Stream Parameters for Management, Intermountain Region, U.S. Department of Agriculture, Forest Service, Ogden, UT. 